\title{
Gender differences in patients presenting with non-ST segment elevation myocardial infarction in the STAR registry
}

\author{
Abdulhalim Jamal Kinsara ${ }^{*}$ (ib and Yasser M. Ismail
}

\begin{abstract}
Background: In most acute coronary artery (ACS) related literature, the female gender constitutes a smaller proportion. This study is based on gender-specific data in the Saudi Acute Myocardial Infarction Registry Program (STARS-1 Program). A prospective multicenter study, conducted with patients diagnosed with ACS in 50 participating hospitals.

Results: In total, 762 (34.12\%) patients were diagnosed with non-ST segment elevation myocardial infarction. Of this group, only 164 (21.52\%) were women. The mean age (64.52 \pm 12.56 years) was older and the mean body mass index (BMI) was higher (30.58 \pm 6.23 ). A significantly proportion was diabetic or hypertensive; however, a smaller proportion was smoking. Hyperlipidemia was present in $48 \%$. The history of angina/MI/stroke and revascularization was similar, except for renal impairment. The presentation was atypical as only $70 \%$ presented with chest pain, and the rest with shortness of breath or epigastric pain. At presentation, the female group were more tachycardiac, had higher blood pressure, and a higher incidence of being in class 11-111 Killip heart failure. Only $32 \%$ had a normal systolic function, and the majority had either mild or moderate systolic dysfunction.

In particular, the rate of percutaneous coronary intervention was similar. The in-hospital mortality was similar (5\%), with more women diagnosed with atrial fibrillation and heart failure at follow-up.
\end{abstract}

Conclusions: Women had a higher prevalence of risk factors affecting the presentation and morbidity but not mortality. Improving these risk factors and the lifestyle is a priority to improve the outcome and decrease morbidity.

Keywords: Gender, NSTEMI, STAR registry

\section{Background}

Gender differences in scientific publications have always been a concern. Such differences may adversely affect the clinical features, management, and most importantly, the outcome [1]. Exploring gender-related data might positively affect the prognosis. A continuous focus on gender differences is important as it improves our understanding [1]. Saudi Arabia, as a developing country, faced the same challenge and this work presents a detailed analysis of data from 50 centers across the country

\footnotetext{
* Correspondence: akinsara@yahoo.com

Department of Cardiology, King Saud Bin Abdulaziz University for Health Sciences, College of medicine, King Abdullah International Medical Research Center, Ministry of National Guard-Health Affairs, Jeddah, Saudi Arabia
}

[2]. The data was extracted from secondary and tertiary hospitals and from different healthcare sectors, including hospitals with and without a catheter laboratory.

\section{Methods}

The STAR is a prospective study of all patients presenting with acute coronary syndrome (ACS) to an emergency department at 50 hospitals across Saudi Arabia. The details of the study have been described previously [2].

The design was a prospective, multi-center, recruited all consecutive AMI (STEMI or NSTEMI) admissions. All relevant data were gathered at admission, 1-month and 1-year follow-up.

\section{Springer Open}

(๑) The Author(s). 2021 Open Access This article is licensed under a Creative Commons Attribution 4.0 International License, which permits use, sharing, adaptation, distribution and reproduction in any medium or format, as long as you give appropriate credit to the original author(s) and the source, provide a link to the Creative Commons licence, and indicate if changes were made. The images or other third party material in this article are included in the article's Creative Commons licence, unless indicated otherwise in a credit line to the material. If material is not included in the article's Creative Commons licence and your intended use is not permitted by statutory regulation or exceeds the permitted use, you will need to obtain permission directly from the copyright holder. To view a copy of this licence, visit http://creativecommons.org/licenses/by/4.0/. 
Table 1 Epidemiological data and presentation characteristics of NSTEMI patients by gender

\begin{tabular}{|c|c|c|c|c|}
\hline & $\begin{array}{l}\text { Male } \\
N=598(78.48 \%)\end{array}$ & $\begin{array}{l}\text { Female } \\
N=164(21.52 \%)\end{array}$ & $\begin{array}{l}\text { Total } \\
N=762\end{array}$ & $P$ value \\
\hline \multicolumn{5}{|l|}{ Variable\# } \\
\hline Age & $56.68 \pm 13.30$ & $64.52 \pm 12.56$ & $58.37 \pm 13.53$ & $<.001$ \\
\hline Saudi & $322(53.85 \%)$ & $137(83.54 \%)$ & $459(60.24 \%)$ & $<.001$ \\
\hline Ethnicity & & & & $<.001$ \\
\hline Arab & $427(71.40 \%)$ & $155(94.51 \%)$ & $582(76.38 \%)$ & \\
\hline South Asian & $152(25.42 \%)$ & $8(4.88 \%)$ & $160(21.00 \%)$ & \\
\hline Others & 19 (3.18\%) & $1(0.61 \%)$ & $20(2.62 \%)$ & \\
\hline BMI & $28.58 \pm 5.33$ & $30.58 \pm 6.23$ & $29.01 \pm 5.59$ & $<.001$ \\
\hline History of angina & $202(33.78 \%)$ & $68(41.46 \%)$ & $270(35.43 \%)$ & 0.068 \\
\hline History of Ml & $139(23.24 \%)$ & $36(21.95 \%)$ & $175(22.97 \%)$ & 0.727 \\
\hline History Ml angina & $241(40.30 \%)$ & $74(45.12 \%)$ & $315(41.34 \%)$ & 0.267 \\
\hline History of $\mathrm{PCl}$ & $109(18.23 \%)$ & $30(18.29 \%)$ & 139 (18.24\%) & 0.985 \\
\hline History of CABG & $32(5.35 \%)$ & $8(4.88 \%)$ & $40(5.25 \%)$ & 0.810 \\
\hline History of heart failure & $54(9.03 \%)$ & $25(15.24 \%)$ & 79 (10.37\%) & 0.021 \\
\hline History of stroke & $30(5.02 \%)$ & $11(6.71 \%)$ & $41(5.38 \%)$ & 0.395 \\
\hline History of chronic renal failure & 49 (8.19\%) & $24(14.63 \%)$ & $73(9.58 \%)$ & 0.013 \\
\hline DM & $334(55.85 \%)$ & $132(80.49 \%)$ & $466(61.15 \%)$ & $<.001$ \\
\hline HTN & $355(59.36 \%)$ & $140(85.37 \%)$ & $495(64.96 \%)$ & $<.001$ \\
\hline Hypercholesterolemia & $245(40.97 \%)$ & 79 (48.17\%) & $324(42.52 \%)$ & 0.098 \\
\hline Current/ex-smoking & $343(57.36 \%)$ & $8(4.88 \%)$ & $351(46.06 \%)$ & $<.001$ \\
\hline Chief complaint & & & & 0.002 \\
\hline Chest pain & $507(84.78 \%)$ & $117(71.34 \%)$ & $624(81.89 \%)$ & \\
\hline SOB/fatigue & $58(9.70 \%)$ & $33(20.12 \%)$ & 91 (11.94\%) & \\
\hline Epigastric/shoulder/back/neck pain & $21(3.51 \%)$ & $10(6.10 \%)$ & $31(4.07 \%)$ & \\
\hline Cardiac arrest & $2(0.33 \%)$ & $1(0.61 \%)$ & $3(0.39 \%)$ & \\
\hline Others & $10(1.67 \%)$ & $3(1.83 \%)$ & $13(1.71 \%)$ & \\
\hline First medical contact & $163(27.26 \%)$ & $27(16.46 \%)$ & $190(24.93 \%)$ & 0.005 \\
\hline Visited emergency department & $142(87.12 \%)$ & 25 (92.59\%) & 167 (87.89\%) & 0.419 \\
\hline Clinic doctor & $27(16.56 \%)$ & $4(14.81 \%)$ & $31(16.32 \%)$ & 0.820 \\
\hline Visited a pharmacy & $3(1.84 \%)$ & $1(3.70 \%)$ & $4(2.11 \%)$ & 0.532 \\
\hline Transferred by Saudi Red Crescent & $15(2.51 \%)$ & $7(4.27 \%)$ & $22(2.89 \%)$ & 0.233 \\
\hline HR (bpm) upon arrival & $84.01 \pm 19.36$ & $91.64 \pm 18.94$ & $85.65 \pm 19.51$ & $<.001$ \\
\hline SBP $(\mathrm{mm} \mathrm{Hg})$ upon arrival & $135.8 \pm 25.56$ & $144.3 \pm 30.82$ & $137.6 \pm 26.99$ & $<.001$ \\
\hline $\mathrm{HR}>100 \mathrm{bpm}$ & $93(15.55 \%)$ & $42(25.61 \%)$ & $135(17.72 \%)$ & 0.003 \\
\hline $\mathrm{SBP}<90 \mathrm{~mm} \mathrm{Hg}$ & $8(1.34 \%)$ & $3(1.83 \%)$ & $11(1.44 \%)$ & 0.640 \\
\hline \multicolumn{5}{|l|}{ Cardiac arrest upon arrival } \\
\hline Cardiac arrest upon arrival & $7(1.17 \%)$ & $1(0.61 \%)$ & $8(1.05 \%)$ & 0.532 \\
\hline \multicolumn{5}{|l|}{ CHF Killip class } \\
\hline Class 1 & $507(84.78 \%)$ & $109(66.46 \%)$ & $616(80.84 \%)$ & $<.001$ \\
\hline Class II/II & $84(14.05 \%)$ & $53(32.32 \%)$ & $137(17.98 \%)$ & \\
\hline IV & $7(1.17 \%)$ & $2(1.22 \%)$ & $9(1.18 \%)$ & \\
\hline \multicolumn{5}{|l|}{ Echo options } \\
\hline Normal LV systolic function (EF > 50\%) & $237(43.33 \%)$ & $53(35.33 \%)$ & $290(41.61 \%)$ & 0.025 \\
\hline
\end{tabular}


Table 1 Epidemiological data and presentation characteristics of NSTEMI patients by gender (Continued)

\begin{tabular}{|c|c|c|c|c|}
\hline & $\begin{array}{l}\text { Male } \\
N=598(78.48 \%)\end{array}$ & $\begin{array}{l}\text { Female } \\
N=164(21.52 \%)\end{array}$ & $\begin{array}{l}\text { Total } \\
N=762\end{array}$ & $P$ value \\
\hline \multicolumn{5}{|l|}{ Variable\# } \\
\hline Mild LV systolic dysfunction (EF 40-50\%) & $164(29.98 \%)$ & $52(34.67 \%)$ & $216(30.99 \%)$ & \\
\hline Moderate LV systolic dysfunction (EF 30-40\%) & $88(16.09 \%)$ & $36(24.00 \%)$ & $124(17.79 \%)$ & \\
\hline Severe LV systolic dysfunction (EF < 30\%) & $58(10.60 \%)$ & $9(6.00 \%)$ & $67(9.61 \%)$ & \\
\hline \multicolumn{5}{|l|}{ ECG done/transferred } \\
\hline ECG done/transferred & $340(56.86 \%)$ & $68(41.46 \%)$ & $408(53.54 \%)$ & $<.001$ \\
\hline \multicolumn{5}{|l|}{ Arterial access } \\
\hline Femoral & $124(46.62 \%)$ & $28(59.57 \%)$ & $152(48.56 \%)$ & 0.101 \\
\hline Radial & $142(53.38 \%)$ & $19(40.43 \%)$ & $161(51.44 \%)$ & \\
\hline
\end{tabular}

The recruiting hospitals were both the one who had catheterization laboratory or not and included various health sectors in Saudi Arabia.

This study aimed to see the difference in the management strategy and the outcome of treatment among male and female patients. This snap shot of two groups will assess if temporal changes in AMI care between genders that were noted among different societies in different studies.

\section{Results}

In total, $762(34.12 \%)$ patients were diagnosed with nonST segment elevation myocardial infarction. Of this group, only 164 (22.52\%) were women. The mean age of the group (64.52 \pm 12.56 years) was older than the male group and the mean body mass index (BMI) was higher $(30.58 \pm 6.23)$. A significantly higher proportion of the female group was diabetic or hypertensive; however, a smaller proportion was smoking. Hyperlipidemia was not significant between the two groups, although present in almost half (48\%) of the female group. The history of
angina/MI/stroke and revascularization was similar, except for renal impairment. The presentation was atypical compared to the male group as only $70 \%$ presented with chest pain, and the rest with shortness of breath or epigastric pain. At presentation, the female group were more tachycardiac, had higher blood pressure, and a higher incidence of being in class 11-111 Killip heart failure. Only $32 \%$ had a normal systolic function, and the majority had either mild or moderate systolic dysfunction (Table 1).

Guideline-directed medical therapy was not different between the two groups, except for the initiation of a beta-blocker on admission. In particular, the rate of percutaneous coronary intervention (PCI) was similar (Tables 2 and 3 ).

Overall, the in-hospital mortality was similar (5\%), and more women were diagnosed with atrial fibrillation and heart failure at follow-up (Table 4). No difference were noted between the groups in recurrent ischemia, recurrent MI, cardiogenic shock, VTVF arrest, stroke, or major bleeding.

Table 2 Medication at admission

\begin{tabular}{|c|c|c|c|c|}
\hline Medications $24 \mathrm{~h}$ & Male & Female & Total & $P$ value \\
\hline Aspirin & $592(99.00 \%)$ & $163(99.39 \%)$ & $755(99.08 \%)$ & 0.640 \\
\hline Clopidogrel & $533(89.13 \%)$ & $154(93.90 \%)$ & $687(90.16 \%)$ & 0.069 \\
\hline Prasugrel & $3(0.50 \%)$ & $0(0.00 \%)$ & $3(0.39 \%)$ & 0.363 \\
\hline Ticagrelor & $59(9.87 \%)$ & $5(3.05 \%)$ & $64(8.40 \%)$ & 0.005 \\
\hline Beta blockers & $531(88.80 \%)$ & $130(79.27 \%)$ & $661(86.75 \%)$ & 0.001 \\
\hline ACEI/ARB & $462(77.26 \%)$ & $132(80.49 \%)$ & $594(77.95 \%)$ & 0.377 \\
\hline Statins & $570(95.32 \%)$ & 159 (96.95\%) & 729 (95.67\%) & 0.363 \\
\hline Aldosterone inhibitor (spironolactone) & $54(9.03 \%)$ & $18(10.98 \%)$ & $72(9.45 \%)$ & 0.451 \\
\hline Heparins UH/LMWH & $552(92.31 \%)$ & $148(90.24 \%)$ & 700 (91.86\%) & 0.392 \\
\hline GP_2b3a_inhibitors & $97(16.22 \%)$ & $15(9.15 \%)$ & $112(14.70 \%)$ & 0.023 \\
\hline Insulin & 284 (47.49\%) & 114 (69.51\%) & 398 (52.23\%) & $<.001$ \\
\hline Oral hp agents & 74 (12.37\%) & 32 (19.51\%) & 106 (13.91\%) & 0.019 \\
\hline
\end{tabular}


Table 3 Medication at discharge

\begin{tabular}{lllll}
\hline Medications discharge & Male & Female & Total & $P$ value \\
\hline Aspirin & $566(98.26 \%)$ & $153(98.08 \%)$ & $719(98.22 \%)$ & 0.875 \\
Clopidogrel & $483(83.85 \%)$ & $132(84.62 \%)$ & $75(84.02 \%)$ & 0.818 \\
Ticagrelor & $61(10.59 \%)$ & $12(7.69 \%)$ & $6.97 \%)$ & 0.284 \\
Beta blockers & $529(91.84 \%)$ & $136(87.18 \%)$ & $665(90.85 \%)$ & 0.073 \\
ACEl/ARB & $457(79.34 \%)$ & $126(80.77 \%)$ & $583(79.64 \%)$ & 0.694 \\
Statins & $562(97.57 \%)$ & $151(96.79 \%)$ & $90(12.30 \%)$ & 0.589 \\
Aldosterone inhibitor (spironolactone) & $65(11.28 \%)$ & $25(16.03 \%)$ & $27(3.69 \%)$ & 0.110 \\
Oral anticoagulant warfarin/dabigatran & $18(3.13 \%)$ & $9(5.77 \%)$ & $268(36.61 \%)$ & 0.120 \\
Insulin & $179(31.08 \%)$ & $89(57.05 \%)$ & $220(30.05 \%)$ & $<.001$ \\
Oral hypoglycemic & $166(28.82 \%)$ & $54(34.62 \%)$ & 0.161 &
\end{tabular}

\section{Discussion}

Women are still underrepresented in ACS-related literature. Based on the gender distribution in the country, we expected a larger proportion, not only $22 \%$ as reported in the current study. Because the data were extracted from the registry, collection bias played no role in the study. Possible explanations could be that the women had ACS but did not reach medical attention or they were incorrectly diagnosed due to their atypical symptoms. Both are major concerns that require further investigation and governmental attention, as previously reported [3, 4].

We also noted the high incidence of diabetes and hypertension in the female group. Both are modifiable risk factors that reflect the need to modify the lifestyle. The medical staff, especially at emergency rooms and paramedics, should be aware of the atypical presentation. The Red Crescent was under-utilized and a mass educational intervention is urgent.

Although the findings are rising alarms, the effort did not match the challenge [5]. The issue is global, extending from east to west [6-8].

Table 4 Outcome differences of NSTEMI patients by gender

\begin{tabular}{lllll}
\hline In-hospital outcomes & Male & Female & Total & $\boldsymbol{P}$ value \\
\hline Recurrent ischemia & $70(11.71 \%)$ & $28(17.07 \%)$ & $98(12.86 \%)$ & 0.069 \\
Recurrent MI & $34(5.69 \%)$ & $14(8.54 \%)$ & $48(6.30 \%)$ & 0.183 \\
Atrial fibrillation/flutter & $28(4.68 \%)$ & $16(9.76 \%)$ & $44(5.77 \%)$ & 0.014 \\
Heart failure & $65(10.87 \%)$ & $34(20.73 \%)$ & $99(12.99 \%)$ & $<.001$ \\
Cardiogenic shock & $32(5.35 \%)$ & $10(6.10 \%)$ & $42(5.51 \%)$ & 0.711 \\
VTVF arrest & $31(5.18 \%)$ & $13(7.93 \%)$ & $44(5.77 \%)$ & 0.182 \\
Stroke & $11(1.84 \%)$ & $3(1.83 \%)$ & $14(1.84 \%)$ & 0.993 \\
Major bleeding & $5(0.84 \%)$ & $1(0.61 \%)$ & $6(0.79 \%)$ & 0.771 \\
In-hospital mortality & $22(3.68 \%)$ & $8(4.88 \%)$ & $30(3.94 \%)$ & 0.484 \\
\hline
\end{tabular}

\section{Conclusion}

Women are underrepresented, frequently had an atypical presentation and presented late. Risk factors are highly prevalent and need immediate attention. It should be stated that when they did present for medical attention, they received appropriate guideline-directed medical therapy and PCI.

\section{Abbreviations}

ACS: Acute coronary artery; STARS-1 Program: Saudi Acute Myocardial Infarction Registry Program; NSTEMI: Non-ST segment elevation myocardial infarction; BMI: Body mass index; PCl: Percutaneous coronary intervention

\section{Acknowledgements \\ None. \\ All authors agree to share their raw data, via IRB office.}

\section{Authors' contributions}

All contributed equally to the preparation and the revision of the manuscript. The authors read and approved the final manuscript. YI: involved in the conception/design of the work; the acquisition, analysis, interpretation of data; had drafted the work. AK: involved in the conception/design of the work, analysis, interpretation of data; had substantively revised it.

Funding

None

Availability of data and materials Via IRB office

\section{Declarations}

Ethics approval and consent to participate

The study was approved by IRB office, King Abdullah International Medical Research Center, number RJ15/008. Informed written consent was obtained anonymously from all participants before they were interviewed.

\section{Consent for publication}

Not applicable

\section{Competing interests}

The authors declare that they have no competing interests.

Received: 19 January 2021 Accepted: 31 May 2021

Published online: 22 June 2021

\section{References}

1. Wang Y, Zhu S, Du R, Zhou J, Chen Y, Zhang Q (2018) Impact of gender on short-term and long-term all-cause mortality in patients with non-ST- 
segment elevation acute coronary syndromes: a meta-analysis. Intern Emerg Med 13(2):273-285. https://doi.org/10.1007/s11739-017-1684-y Epub 2017 May 24.PMID: 28540660 Review

2. Alhabib KF, Kinsara AJ, Alghamdi S, Al-Murayeh M, Hussein GA, AlSaif S, Khalaf H, Alfaleh H, Hersi A, Kashour T, Al-Saleh A, Ali M, Ullah A, Mhish H, Abdo AN, Almutairi F, Arafah MR, AlKutshan R, Aldosari M, AlSabatien BY, Alrazzaz M, Maria AM, Aref AH, Selim MM, Morsy AM, AlTohari FA, Alrifai AA, Awaad AA, El-Sayed H, Mansour S, Atwa AA, Abdelkader S, Altamimi N, Saleh E, Alhaidari W, ElShihawy EHA, Busaleh AH, Abdalmoutaleb M, Fawzy EM, Mokhtar Z, Saleh AM, Ahmad MA, Almasswary A, Alshehri M, Abohatab KM, AlGarni T, Butt M, Altaj I, Abdullah F, Alhosni Y, Osman HB, Bugti N, Aziz AA, Alarabi A, AlHarbi IA (2019) The first survey of the Saudi Acute Myocardial Infarction Registry Program: main results and long-term outcomes (STARS-1 Program). PLoS One 14(5):e0216551. https://doi.org/1 0.1371/journal.pone.0216551 eCollection 2019

3. Hersi A, Al-Habib K, Al-Faleh H, Al-Nemer K, Alsaif S, Taraben A et al (2013) Gender inequality in the clinical outcomes of equally treated acute coronary syndrome patients in Saudi Arabia. Ann Saudi Med 33(4):339-346 https:// doi.org/10.5144/0256-4947.2013.339. PMID: 24060711

4. Kalaf H, AlMesned A, Soomro T, Lasheen W, Ewid M, Al-Mohaimeed AA (2016) Cardiovascular disease risk profile among young Saudi women of AlQassim, Saudi Arabia: a cross-sectional study. Int J Health Sci (Qassim) 10(1): 29-37. https://doi.org/10.12816/0031214 PMID: 27004055

5. Varghese T, Wenger NK (2018) Non-ST elevation acute coronary syndrome in women and the elderly: recent updates and stones still left unturned. F1000Res 7:F1000 Faculty Rev-1865. https://doi.org/10.12688/f1000research.1 6492.1

6. Eindhoven DC, Hilt AD, Zwaan TC, Schalij MJ, Borleffs CJW (2018) Age and gender differences in medical adherence after myocardial infarction: women do not receive optimal treatment - the Netherlands claims database. Eur J Prev Cardiol 25(2):181-189. https://doi.org/10.1177/20474 87317744363

7. Sobers N, Rose AMC, Samuels TA, Critchley J, Abed M, Hambleton I, Harvey A, Unwin N (2019) Are there gender differences in acute management and secondary prevention of acute coronary syndromes in Barbados? A cohort study. BMJ Open 9(1):e025977. https://doi.org/10.1136/bmjopen-2018-02 5977

8. Zamzamy R, Kinsara AJ (2018) Gender inequity in cardiovascular care global perspective. JAPI 66(7):80-82.

\section{Publisher's Note}

Springer Nature remains neutral with regard to jurisdictional claims in published maps and institutional affiliations.

\section{Submit your manuscript to a SpringerOpen ${ }^{\circ}$ journal and benefit from:}

- Convenient online submission

- Rigorous peer review

- Open access: articles freely available online

- High visibility within the field

- Retaining the copyright to your article

Submit your next manuscript at $\boldsymbol{\nabla}$ springeropen.com 